\title{
The Impact of the Global Financial Safety Net on Emerging Market Bond Spreads ${ }^{1}$
}

\author{
Jenny Kilp, Deutsche Bundesbank; \\ Embassy of the Federal Republic of Germany in South Africa \\ jenny.kilp@bundesbank.de \\ Vafa Anvari, South African Reserve Bank \\ vafa.anvari@resbank.co.za \\ Samantha Springfield, South African Reserve Bank \\ samantha.springfield@resbank.co.za \\ Crystal Roberts, South African Reserve Bank \\ crystal.huntley@resbank.co.za
}

Following the 2007-2008 global financial crisis, it became evident that there was a need for a strengthening of the global financial safety net (GFSN). The manner in which this should be achieved became a polarising issue of debate in international institutions such as the International Monetary Fund and the G20. Empirical evidence concerning the impact of the GFSN remains scarce. Therefore, this paper seeks to contribute to the debate by investigating the potential impacts that the various layers of the GFSN can have on sovereign borrowing costs in emerging markets. This analysis first reviews the common methodologies that can be found in the literature concerned with identifying determinants of foreign currency sovereign spreads in emerging markets. The analysis is then expanded to include elements of the GFSN. The results indicate that whilst the liquidity buffers provided by the overall GFSN appear to lower sovereign spreads, the impact of individual layers of the safety net is more ambiguous.

Keywords: global financial safety net, sovereign yields, emerging markets

JEL Codes: F33; F55; F32
Citation: Kilp, J., Anvari, V., Springfield, S. and Roberts, C. (2019). The Impact of the Global Financial Safety Net on Emerging Market Bond Spreads. Russian Journal of Money and Finance, 78(2), pp. 43-66.

doi: $10.31477 /$ rjmf.201902.43

\footnotetext{
${ }^{1}$ This paper should not be reported as representing the views of the South African Reserve Bank or the Deutsche Bundesbank. The views expressed are those of the authors and do not necessarily reflect those of either institution.
} 


\section{Introduction}

In the aftermath of the 2007-2008 global financial crisis (GFC), a vibrant debate has emerged regarding what countries can do to enhance their resilience to external shocks. Specifically, policy makers have asked what could be done, on a regional and global level, to better insulate countries against global financial market volatility and to prevent the international spillover effects of financial crises.

As a consequence, the GFC has once again placed the global financial safety net (GFSN) - which is traditionally comprised of the International Monetary Fund (IMF) resources and a country's foreign exchange reserves - in the spotlight. The turmoil in financial markets, the hesitation to use IMF resources during crisis periods, and the perceived need for better crisis prevention and resolution have led to new instruments being added to the GFSN. ${ }^{2}$ Concomitantly, the financial resources available within the safety net have increased substantially, not only on the global and regional levels, but also domestically, as countries continue to accumulate foreign exchange reserves.

The discussion concerning how the GFSN should further evolve remains heated, especially with regard to its size, coverage, and access. Many emerging markets (EMs) argue that GFSN coverage is uneven, which is perceived as a hindrance to effective crisis prevention and resolution. However, the global financial safety net is invariably a complex issue - particularly given the potential for moral hazard - from the perspective of both market participants and policy makers. This raises a number of policy issues, such as the optimal design of the GFSN, the interaction of the different instruments, and the degree of cooperation that is required, both multilaterally and with international organisations such as the IMF. These issues remain relevant in light of the persistence of financial market volatility that is related to enduring financial, economic, and policy uncertainty worldwide, especially considering that many countries are left with significantly reduced macroeconomic policy buffers relative to pre-GFC levels.

In order to facilitate a more robust policy debate around these issues, this paper contributes to the limited body of empirical work on the GFSN. The paper investigates whether countries' diverse access to the various layers of the GFSN in terms of volume and overall availability - has had an influence on the perceived riskiness of the country. This is achieved by analysing the impact that the different layers of the GFSN have had on foreign currency denominated sovereign bond spreads, after controlling for domestic economic fundamentals, and external conditions.

\footnotetext{
${ }^{2}$ Such as an increased number of regional/multilateral financing arrangements (RFA/MFA); a broader network of swap line facilities and the IMF Flexible Credit Line and Precautionary Liquidity Line.
} 


\section{Overview of the literature on emerging market bond spreads}

There is a vast body of literature concerned with understanding the drivers of EM foreign currency bond spreads. Despite differing on certain details, many of the conclusions drawn from said literature can be summed up as follows: (i) both global and domestic factors are relevant; (ii) global conditions are more important in the short term, while macroeconomic fundamentals are more important in the long term; (iii) better macroeconomic fundamentals can reduce the impact of global risk factors on spreads; and (iv) misalignments can play a substantive role.

In his seminal paper on the subject, Edwards (1983) found that countryspecific fundamentals, including external debt, debt service ratios, and foreign exchange reserves, tend to be the main drivers of spreads. More recently, studies have determined that global factors such as global liquidity, the level of international interest rates, risk aversion, and uncertainty are equally important. Additionally, the extent of foreign participation in a country's local bond market plays a role, as do fiscal variables and political risk.

The influence of global factors on EM bond spreads has become more significant, given both the increased level of financial integration worldwide and the development and increased issuance in emerging market fixed income markets since the late 1990s. Macroeconomic fundamentals in emerging markets have similarly improved over time, with a resulting improvement in sovereign credit ratings that has led to increased investor demand. In addition, since the GFC, the search for yield - combined with greater liquidity in global financial markets - has increased the appetite for and issuance of emerging market debt. The Bank for International Settlements (BIS) has noted that, as emerging markets become ever more integrated in the global economy, and with the rise of 'crossover investors', global, or common factors may become more important determinants of EM bond spreads relative to idiosyncratic factors. ${ }^{3}$

An IMF staff study by Bellas et al. (2010) incorporated the Emerging Markets Financial Stress Index (FSI) 4 in order to capture the state of a country's financial health, and found that it is a crucial factor in determining short-term spread movements. Other factors such as political risk and macroeconomics were found to be more significant determinants in the long run. Csonto and Ivaschenko (2013) find that global factors play a more prominent role in the short run, while the strength of fundamentals affects the sensitivity of the country's risk premium

\footnotetext{
${ }^{3}$ Mc Guire and Schrijvers (2003).

${ }^{4}$ The FSI comprises five variables; the banking sector beta (or the standard capital asset pricing model beta); stock market returns; time varying stock market return volatility; sovereign debt spreads and an exchange market pressure index which captures exchange rate depreciations and declines in international reserves.
} 
to global factors in the long run. Furthermore, there are often misalignments between observed emerging market bond spreads and those implied by a country's macroeconomic fundamentals. For example, instances of underpricing of emerging market debt tend to increase in periods of severe stress, exacerbated by limited understanding of country-specific developments. In this regard, Csonto and Ivaschenko (2013) find that declines in post-GFC spreads and inflows of funds to emerging markets only reflect an improvement in fundamentals to a limited extent.

Similar to much of the literature regarding emerging market sovereign bond spreads, this paper investigates the determinants of the JPMorgan Emerging Market Bond Index Global (EMBIG). ${ }^{5}$ It considers global and domestic macroeconomic fundamentals, financial variables, political risk factors and the role of the GFSN in explaining movements in emerging market bond spreads. In essence, this paper's contribution to the literature can be seen as an extension of Maurini (2017), who focused on the impact of IMF resources and programmes on EMBIG spreads.

\section{The global financial safety net}

There is no single definition of the term 'global financial safety net'. However, most authors define the GFSN from a purely financial point of view, including in its definition some combination of foreign exchange reserves and official arrangements (bilateral swap arrangements (BSAs), regional financial arrangements $^{6}$ (RFAs) and IMF resources). ${ }^{7}$ A recent IMF definition also includes market-based instruments, such as commodity price hedges and catastrophe or GDP-linked bonds (IMF, 2016). The European Central Bank (ECB) takes a much broader perspective by defining the GFSN as 'a diverse set of institutions and mechanisms which can contribute to preventing and mitigating the effects of economic and financial crisis' (ECB, 2016, p. 36). This broad definition could also encompass a country's institutions, policies, and economic fundamentals. As the research question of this paper requires the ability to distinguish between the impact of a country's economic fundamentals on the one hand, and the financial alternatives available to reduce liquidity risk in times of stress on the other, it is practical to adhere to the narrower definition of the GFSN, comprising of foreign exchange reserves, BSAs, RFAs, and IMF resources.

\footnotetext{
${ }^{5}$ The EMBIG tracks the total returns for traded external emerging market debt instruments. It includes USD denominated Brady bonds, loans, and Eurobonds with an outstanding face value of at least USD 500 million and 2.5 years to maturity at the time it is added to the index.

${ }^{6}$ These also include Multilateral Financing Arrangements, such as the Contingent Reserve Arrangement which exists within the BRICS grouping.

${ }^{7}$ Scheubel and Stracca (2016) provide an in depth primer into the origins and rationale of the GFSN, together with a comprehensive dataset for analytical work.
} 


\subsection{International reserves}

The concept of self-insurance, and specifically the role foreign exchange reserves play in it, has always been key to any discussion of the GFSN. In essence, foreign exchange reserves serve as an instrument to reduce perceived vulnerabilities. The idea is that foreign exchange reserves may help a country to transitionally satisfy the demand for foreign exchange in the event the supply is disrupted by shocks to the trade or capital account balance (IMF, 2015). In conjunction with sound economic and financial policies, a strong buffer of foreign exchange reserves may provide some level of assurance to foreign investors that they will be paid back in times of crisis, potentially decreasing a country's risk premium.

A primary argument in favour of increasing the scope and coverage of RFAs is that foreign exchange reserves as an instrument for self-insurance can be costly to accumulate and inefficient to utilise. The common practice of investing in liquid public liabilities provides lower returns relative to other investment opportunities, and is not without risks (Aizenman et al., 2010). Additionally, the sterilisation costs that accompany foreign exchange acquisition can sometimes carry a higher interest cost than the return earned on the reserve assets (Dominguez et al., 2011). A number of authors claim, however, that the cost of holding reserves might be significantly overstated by just looking at interest rate differentials. For example, Levy-Yeyati (2008) points out that foreign currency reserves are usually purchased in times of low-risk spreads and appreciated exchange rates, and sold in times of high-risk spreads and depreciated exchange rates, leading to positive valuation gains. Moreover, he illustrates in his analysis that higher reserves holdings tend to decrease the risk of a sovereign default and thereby reduce the risk spread paid on the stock of sovereign debt and potentially also the spread for private borrowers - a result this paper hopes to test or replicate.

Foreign exchange reserves are a country's own resources that can be used with no conditions or repayment obligations attached, thus providing a strong incentive for a country to rely to some extent on this form of self-insurance. Indeed, foreign exchange reserve buffers started growing rapidly after the East Asian financial crisis, with emerging markets and developing countries (EMDCs) doubling their foreign exchange reserves holdings as a percent of GDP since the early 1990s (IMF, 2016). In fact, individual countries' foreign exchange reserves make up the largest component of the GFSN, having risen from USD 6.5 trillion in 2005 to just under USD 11.3 trillion in 2017 Q3. ${ }^{8}$ Over half of these reserves are held in USD, although this proportion has declined steadily from around $75 \%$ in the mid-1990s.

\footnotetext{
${ }^{8}$ IMF, Currency composition of Official Foreign Exchange Reserves.
} 


\subsection{International Monetary Fund (IMF)}

The IMF has traditionally been at the centre of the GFSN, as it has the surveillance mandate (to review the policies of its member countries with regard to achieving external stability), and is tasked to provide foreign exchange financing in cases of transitional balance of payments needs. In the past, the IMF has typically been an important source of foreign exchange support for this. In cases when market financing is either not accessible or not affordable, the IMF provides financing through its conventional programmes at interest rates that are independent of a country's risk profile. It also attaches macroeconomic conditionality to the programme in order to solve a country's transitory liquidity problems, and to ensure the repayment of debt. However, this attached conditionality is increasingly seen as a disadvantage and a deterrent to using IMF financing, as it is perceived by many as an undesirable interference in domestic policies. Others also believe that the determination of such conditionality is not always approached in an evenhanded or objective manner. Furthermore, access to resources under conventional IMF programmes is generally limited. It depends on a country's quota at the IMF, although exceptional financial access can be granted under specific circumstances.

The IMF's surveillance, lending capacity, and its financing instruments have been considerably enhanced and expanded as a result of the GFC. Due to the international contagion effects experienced during the GFC, in 2009 the IMF added precautionary instruments to its toolkit to protect those members which had been affected by regional or global stress-induced spillovers. Subsequently, the flexible credit line (FCL), available to countries with very strong macroeconomic fundamentals and policies, and the precautionary liquidity line (PLL), available to countries with sound policies and only low vulnerabilities, were created. The commitment of resources under both facilities is based upon pre-qualification criteria and requires a commitment fee. Once a country has been approved for a precautionary tool, it can draw on resources without further justification, thereby assuring market participants that liquidity will be provided quickly in times of stress, avoiding a rush to exit.

Since its introduction in 2009, only three countries have used the FCL and only one country has used the PLL. This low level of utilisation is often attributed to the stigma that remains attached to IMF financing. It appears that member countries fear signalling vulnerabilities to capital markets by applying for money through the FCL or the PLL. Additionally, there is some uncertainty regarding the signals that will be sent by withdrawing from such instruments, as financial markets might consider the relevant country to have a lower level of creditworthiness, since it has fewer available 'reserves.'

\footnotetext{
${ }^{9}$ In November 2017, Poland decided to end its arrangement under the FCL, with seemingly limited negative impact on its financial markets or perceived strength in managing external vulnerabilities.
} 
The empirical evidence concerning the effectiveness of IMF resources and instruments on emerging market bond spreads shows mixed results. Maurini (2017) finds a positive impact from the overall size of IMF resources, measured by its Forward Commitment Capacity (FCC), on the risk outlook and borrowing costs of emerging markets, regardless of the type of IMF programme used by members. The evidence with regard to the effectiveness of the new precautionary facilities (FCL, PLL) remains, however, inconclusive. Izquierdo and Talvi (2009) and IMF (2014) find that the introduction of the new precautionary IMF instruments has had a significant positive impact on the bond spreads of countries that either received access, or were deemed eligible by the investment community for the new facilities. On the other hand, Maurini (2017), as well as Fernandez-Arias and Levy-Yeyati (2010), fail to find a significant impact from the introduction of these programmes.

In another recent study, Essers and Ide (2019) try to evaluate the impact of the FCL on EMBIG spreads and gross capital inflows. They use a counterfactual approach that relies on comparing the evolution of these variables in each country that has access to the FCL against a synthetic control group, consisting of a group of global or regional emerging market countries. The conclusion is that the FCL has moderate beneficial effects which, "in the case of spreads became visible only a considerable time after the respective FCLs were first approved".

\subsection{Bilateral swap line agreements (BSAs)}

Swap lines between central banks are contingent arrangements that enable a receiving central bank to obtain foreign currency from another central bank, for a fee. Usually, the issuing central bank provides its domestic currency for a fixed term at the market exchange rate in exchange for domestic currency or other assets pledged by the receiving central bank. At maturity, the same exchange rate is used to reverse the transaction, with an interest cost charged by the issuing central bank. However, there can also be arrangements where one central bank lends its currency reserves to another central bank. The exchange rate may be predetermined and, in some cases, terms are not limited. The central bank that provides liquidity usually carries the credit risk of the receiving central bank, meaning that it is exposed to exchange rate risk if the receiving central bank is not able to repay in foreign exchange (Denbee et al., 2016; ECB, 2016).

While originally used to influence a country's domestic liquidity situation or foreign exchange rates, more recent BSAs have been used to provide foreign currency liquidity to the domestic financial system, usually against collateral. They are thus primarily seen as an instrument to ensure the functioning of foreign currency markets in times of stress and to mitigate the potential spillover effects of dysfunctional markets on financial stability and the real economy within and across jurisdictions. 
Both during and in response to the GFC, the use of BSAs between central banks increased rapidly between reserve issuing central banks, other advanced economies (AE), and a few emerging markets. ${ }^{10}$ Most of these agreements were short-term in nature and have already expired or been terminated. However, an unlimited and standing bilateral swap network has been established between the ECB, the Federal Reserve of the United States, the Bank of England, the Bank of Canada, the Bank of Japan, and the Swiss National Bank. This network mirrors the concentrated global banking network among AEs, in particular the UK, US, and Japan, as well as several other countries from the European Union (IMF, 2016; ECB, 2016). The People's Bank of China (PBoC) appears to be the most active provider of BSAs, and according to Volz (2016), in February 2016 the PBoC had 31 active swap lines totalling USD 500 billion.

BSAs do not have macroeconomic conditionalities attached to their activation, making them more attractive than other layers of the GFSN to some countries; however, they do incorporate established risk management factors. In this regard, BSAs take into account credit risk through collateral requirements, the amount of the haircuts, or the interest rate costs associated with them. Despite these risk management factors, and because there are no macroeconomic conditionalities attached, there appears to be less stigma attached to their use. However, every central bank has its own preconditions when it enters into an agreement with a central bank that has requested assistance through swap lines, largely dependent on the mandate of the lending central bank. Therefore, the worldwide coverage of the network of BSAs remains limited, and the conditions that have to be met in order for a lending central bank to agree to a BSA are seldom fully transparent. Most reserve currency issuing central banks do not see BSAs as a substitute for other elements of the GFSN. In particular, they do not view them as an appropriate instrument to finance balance of payments needs (ECB, 2016).

\subsection{Regional financing arrangements (RFAs)}

The IMF defines RFAs as "financing mechanisms through which a group of countries in a region pledges financial support to members that are experiencing, or might experience, a liquidity shortage or balance of payments difficulties" (IMF, 2013). They can be seen as arrangements that range between self-insurance and multilateral assistance from the IMF.11

\footnotetext{
${ }^{10}$ For example, the Federal Reserve of the United States set up a swap line with Brazil; the ECB with Hungary, Latvia, and Poland (IMF, 2016).

${ }^{11}$ The RFAs that currently exist are the European Stability Mechanism (ESM), the Chiang Mai Initiative Multilateralisation (CMIM), the BRICS Contingent Reserve Arrangement (CRA), the Arab Monetary Fund (AMF), the Eurasian Fund for Stabilization and Development (EFSD), the European Union BoP assistance facility (EU BoP), the Fondo Latinoamericano de Reservas (FLAR), the North American Framework Agreement (NAFA) and the South Asian Association for Regional Cooperation (SAARC) (IMF, 2016).
} 
These RFAs differ not only with regards to their purpose and set-up, but also in the conditions under which they disburse financial resources. Some arrangements have lending instruments suitable for different financing problems, for example the European Stability Mechanism (ESM), the Fondo Latinoamericano de Reservas (FLAR) or the Arab Monetary Fund (AMF). Others have agreements to provide bilateral swap lines when a member needs foreign currency. While the latter usually involves the provision of the member's foreign exchange reserves, other RFAs are funded from the fiscal budget, in some cases leveraged with capital market borrowing. Most of the RFAs attach some form of macroeconomic conditionality to a disbursement, at least in the case of the disbursement exceeding a certain threshold. Furthermore, obtaining financing beyond a pre-stipulated threshold also often requires the existence of a parallel IMF programme, as is the case with the CMIM or the CRA. The amount of resources available under the RFAs also varies significantly, ranging from about USD 2 billion in smaller arrangements like the SAARC, to EUR 500 billion, as is currently available under the ESM (ECB, 2016). At the same time, the total amount of resources committed under RFAs, about USD 1.3 trillion, is greater than the approximately USD 1 trillion of currently available IMF resources (IMF website, 2017).

While the ESM was actively used during the Eurozone sovereign debt crisis, to date the next two largest RFAs, the CMIM and the CRA, have not been used. It is therefore difficult to assess the effectiveness of RFAs in crisis resolution. Questions arise as to why so many RFAs are either not used, or are used rather sporadically, especially since several of the arrangements also offer precautionary credit lines or swap lines. One advantage of RFAs is that in times of crisis, they enable a potentially faster decision-making process, as RFAs have a limited number of members, which are usually located in the same geographical region, and may therefore have a deeper knowledge of the problem facing a certain member. Furthermore, members of the RFA have an interest in preventing potential spillover effects on their own economies. Additionally, there might be less negative stigma associated with turning to a 'neighbour' for funding rather than asking the IMF for financial resources. The major disadvantage of RFAs is that most of them have a limited amount of available resources, which makes them more suited to respond to idiosyncratic rather than to region-wide shocks. Furthermore, RFAs in general tend to be rather new constructs and thus have not yet been tested. Acknowledging these disadvantages, the G20 countries have set an objective to improve cooperation between the IMF and RFAs. Such cooperation has so far only been tested during the Eurozone sovereign debt crisis, where both the IMF as well as the European RFAs (EFSF, ESM) contributed financial assistance to Eurozone countries.

\subsection{Controversy around the GFSN}

There appears to be a common understanding that prudent economic and financial policies, together with sound institutions, are of utmost importance to 
shield a country from excessive market volatility and to prevent and mitigate the impacts of a financial crisis. However, there is also a general understanding that financial backstops from the IMF and from RFAs and BSAs are useful and necessary to help prevent and mitigate the impacts of an economic or financial crisis. Given the increased role and weight of emerging markets in the global economy, it is necessary to ensure appropriate and sufficient access to the GFSN for emerging market countries.

At the same time, opinions differ as to whether there is a need for a more centralised GFSN, including new instruments and greater resources at the IMF, in order to improve the coverage, effectiveness, and certainty of the safety net. The root of this controversy can partly be explained by the potentially conflicting goals that the GFSN is expected to achieve. Firstly, it is expected to be a means for crisis prevention by reassuring investors that money will be available to repay outstanding debt in times of a liquidity crisis. Through this role, the spillover effects of a crisis can be contained and innocent bystanders can be ring-fenced. Secondly, it is supposed to provide sufficient financing in the event of a crisis. Thirdly, the GFSN is expected to incentivise sound financial policies as a means of crisis prevention or macroeconomic adjustment in case a crisis presents itself.

Providing financing whilst simultaneously setting sound policy incentives is a complex task. To give an extreme scenario, if one assumed that the IMF had access to unlimited resources and offered its members uncapped swap lines with no macroeconomic conditionality attached, the likely outcome would be a situation where governments and investors had perfect certainty that financing would be available in times of crisis. At the same time, the incentives for the governments to build up their own buffers for crisis prevention and resolution would decrease, with all the liquidity and credit risks being shifted to the international community that funds the IMF. It is also likely that investors would rely on this promise given by the IMF rather than pricing a country's risk premium according to its economic fundamentals.

On the other hand, a scenario where GFSN coverage would be structurally uneven, with large gaps existing particularly amongst emerging market economies, is clearly not optimal. In the event of crisis, such gaps would lead to more costly spillover effects which spread more quickly. The GFC is a case study in the consequences of a crisis that originated in AEs, which have the broadest access to the GFSN, but which then spread to EMs, which were perhaps ill-equipped to deal with the external headwinds. This sentiment was well encapsulated in a recent IMF study (IMF, 2016, p. 2): "Reserve currencyissuing advanced economies (AEs) are best served by the current GFSN, while non-systemic, non-gatekeeper EMs are the least adequately served. Systemic and gatekeeper EMs also have inadequate predictability and reliability (from BSAs and RFAs), and high financial costs (from reserve accumulation) or political costs (from stigma associated with Fund financing)". 
The relevance of the concerns about the incentives and the current size of the GFSN, all elements included, to safeguard global financial stability, remains debated. However, taking into account the existing bilateral, regional and multilateral financing mechanisms and instruments, there appears to be an understanding that some kind of qualification criteria and/or ex-post conditionality need to remain in place in order to reduce the credit risks for the counterparties, and to set appropriate incentives concerning countries' own crisis prevention efforts. In this context, studies such as this one could be useful to shed some light on how investors actually take account of different elements of the GFSN in their risk pricing.

\section{Empirical model and data}

In line with one of the standard approaches in the literature, a simplified version of the empirical model developed by Edwards (1983) is adopted. The equilibrium condition for a price-taking risk-neutral investor who invests in a country with a non-zero probability of default is the following: ${ }^{12}$

$$
(1-p)\left(1+i^{*}+s\right)=\left(1+i^{*}\right)
$$

where $p$ is the probability of default, $i^{*}$ is the risk-free interest rate, and $s$ is the county-specific risk premium. Based on this condition, the investor receives compensation in the form of the country-specific risk premium to account for the non-zero probability of default, represented as the following:

$$
s=\frac{p}{1-p} *\left(1+i^{*}\right) \text {. }
$$

Under common assumptions regarding the nature of $p$, the country risk premium (or spread) can be written as a linear function of the determinants of $p$ :

$$
\ln s=\ln \left(1+i^{*}\right)+\sum_{i} \beta_{i} X_{i}
$$

where $X_{i}$ represents a matrix of the determinants of the probability of default. ${ }^{13}$

With this framework in mind, an unbalanced panel of quarterly data from 21 emerging market economies ${ }^{14}$ is considered, spanning from 1997 to 2016. A quarterly average of the sovereign bond spread, taken from the JPMorgan EMBIG, is used as the dependent variable. The EMBIG considers market capitalisationweighted averages of spreads above a comparable US government bond for debt instruments issued by sovereigns, or quasi sovereigns, which meet certain

\footnotetext{
${ }^{12}$ Assuming that the recovery rate in the case of default is zero.

${ }^{13}$ Including determinants of solvency and liquidity risk.

14 The following countries are included in the dataset: Argentina, Brazil, Bulgaria, Chile, China, Colombia, Croatia, Ecuador, Hungary, India, Indonesia, Malaysia, Mexico, Peru, Philippines, Poland, Russia, South Africa, Thailand, Turkey, and Ukraine.
} 
liquidity criteria. The EMBIG is widely used in the relevant literature, as it provides continuous time series which serve as a good proxy for the evolution of marketperceived sovereign risk.

With respect to the risk-free rate, the yield on 10-year US government bonds (US10) emerges as the obvious candidate. For robustness, other candidate interest rates further down the yield curve, including the 3-month US government bond yield and the Fed Funds rate, were also tested.

The explanatory variables used in the various equation specifications fall into three broad categories: global factors, country-specific fundamentals and GFSN factors. Each of these is discussed below.

\subsection{Global factors}

There are broadly two categories of external factors which are frequently identified in the literature as driving sovereign spreads: risk aversion and global liquidity. For simplicity's sake, here the Chicago Board Options Exchange Volatility Index (VIX) is used, which measures the implied volatility of S\&P index options. This widely utilised variable is expected to be positively correlated with sovereign spreads, as an increase in global volatility serves as a proxy for risk appetite in this scenario. As a measure of EM-specific sentiment, annual returns on the Morgan Stanley Capital International (MSCI) EM index are also considered.

\subsection{Country-specific fundamentals}

In agreement with Comelli (2012), Csonto and Ivaschenko (2013) and others, it is suggested that country-specific fundamentals driving sovereign spreads can be divided into three categories: economic risk factors, financial risk factors, and political risk factors. However, unlike much of the recent literature in this area, third party risk indicators are avoided (for the most part) and country-level data collected from national authorities are used instead.

In order to capture economic risk, annualised growth in real GDP (rGDP), annual consumer price inflation (CPI), the seasonally adjusted current account balance $(\mathrm{CAB})$ as a percentage of GDP and a four-quarter moving average of the fiscal balance $(\mathrm{FB})$ as a percentage of GDP are considered. It is anticipated that both rGDP and FB will be negatively correlated with sovereign spreads, as they both directly impact the sovereign's balance sheet. Consumer inflation has a wellestablished positive relationship with domestic currency bond yields; however, with respect to foreign currency bonds a positive relationship is anticipated if it can serve as a proxy for macroeconomic policy stability.

The literature on the impact of the current account balance on sovereign spreads presents a mixed view. Giordano et al. (2012) and De Grauwe and Ji (2013) find a negative relationship between the $\mathrm{CAB}$ and sovereign spreads. They suggest that an 
improvement in the $\mathrm{CAB}$ signals competitiveness and an ability to raise funds for the servicing of debt, and therefore spreads are likely to decline. On the other hand, a worsening $\mathrm{CAB}$ could imply an increase in net-foreign debt, which undermines the government's ability to meet its obligations (directly or indirectly), resulting in an increase in spreads. Conversely, Malritz (2012) finds that the relationship could be positive, arguing that a current account surplus is offset by a capital account deficit, and so the associated capital outflow may signal capital flight or the inability of a country to borrow from abroad, thereby causing sovereign spreads to rise.

To measure financial risk determinants, a measure of external debt (ExD) and gross government debt $(\mathrm{GvD})$, both expressed as a percentage of GDP, are included, in addition to a measure of domestic currency volatility calculated using a standard GARCH model (GVol). The debt measures are expected to have the standard positive relationship with sovereign spreads, whilst GVol is expected to act as a measure of domestic financial stability.

It is somewhat more challenging to measure political risk quantitatively, therefore The Economist Intelligence Unit's political risk index (EIP) is included in the dataset as a proxy. This index tracks political risk on a scale from 1 (low) to 100 (high) for each country in the sample and the a priori expectation is for it to be positively correlated to bond spreads.

\subsection{GFSN factors}

The impact of the GFSN is captured by variables (or proxies) for each of the four layers of the GFSN discussed above. Data on international reserves (IntRes) and bilateral swap lines (BSA) are collected from national central banks and expressed as a percentage of GDP. Information on regional financing arrangements (RFA) was collected from publicly available sources, scaled to represent each member's access to the RFA, rather than the total size of the arrangement, and similarly represented as a percentage of GDP.

There are a number of possible approaches to measuring the impact that IMF resources have on sovereign spreads. One such approach was put forward by Maurini (2017), who collected information on the IMF's forward commitment capacity (FCC) from regularly published IMF statements. ${ }^{15}$ Maurini argues that the overall signalling effect of IMF resources has the effect of lowering sovereign spreads across EMs. Since the FCC variable exhibits potential evidence of a unit root, it is expressed as a ratio of world GDP - which is in turn taken from the IMF World Economic Outlook database. Furthermore, information on IMF programmes is also considered, with dummies to represent countries that had active IMF programmes (IMFprog) as well as a subset thereof which only considers precautionary IMF programmes (IMFprec). Finally, data on the three countries that took up IMF FCLs

\footnotetext{
${ }^{15}$ It is also possible to scale available IMF resources by each member's quota voting share to find a floor for potential access and express as a percentage of domestic GDP (FCCq).
} 
are included to test the hypothesis that these new precautionary instruments can lower perceived risk. FCL access is included as a percentage of local GDP (FCL) and as a dummy variable (FCLdum).

Edwards (1983) referred to international reserve holdings as a likely determinant of the cost of repudiating debt, as foreign assets may be claimed easily by foreign creditors in the event of default, and penalties from the international community may be harsher on countries that default, but still maintain liquid reserves. It is also often argued that international reserve holdings should lower the liquidity risk of a country. Accordingly, a negative relationship between international reserves and spreads is anticipated. In this vein, it is similarly expected that the other GFSN variables could serve as potential liquidity indicators. Access to IMF and RFA resources are obvious candidates to form a liquidity buffer. Concerning BSAs, one could argue that they are intended to provide liquidity to central banks that are then able to provide such liquidity to financial market participants so as to ensure that markets are able to function smoothly. Ultimately, BSAs are commonly included as part of the GFSN because they help reduce the probability that financial institutions might default, and therefore decrease the probability of the need for a public bailout, which, in turn, would reduce the sovereign probability of default.

Since the a priori expectation is for each layer of the GFSN to have a negative correlation with sovereign spreads, it is also possible to consider a measure which pools access from each of the GFSN layers into one variable representing aggregated GFSN access (GFSNacc). ${ }^{16}$

\section{Methodology}

Sections of the literature (such as Csonto and Ivaschenko, 2013) suggest that country-specific factors may differ in the short and long term. To account for the potentially dynamic nature of the problem (and to accommodate any heterogeneity in the panel) they propose the use of the pooled mean group (PMG) estimator developed by Pesaran et al. (1999), which essentially allows for country-specific short-run estimates. However, estimators of this type have difficulty when dealing with panels which include dummy variables. This is left as a potential area for future research.

In line with the vast majority of the literature, equation (3) is estimated using panel ordinary least squares regression with fixed effects. The validity of this approach is confirmed using a Hausman test. Furthermore, to control for any potential endogeneity issues, the relevant domestic variables are lagged in the estimation.

To replicate in part the results of papers such as Bellas et al. (2010), Comelli (2012) and Csonto and Ivaschenko (2013), initially only global and domestic factors are

${ }^{16}$ GFSNacc $=$ IntRes + BSA + RFA + FCCq 
considered in specifications [1] to [4] in Table 3 in the Appendix. The measure of aggregated GFSN access is then added. Next, in order to assess the disaggregated impacts of each layer of the GFSN, specifications with individual GFSN layers are presented in Table 4 in the Appendix. Finally, the impact of various measures of IMF programmes is presented in Table 5 in the Appendix.

\section{Results}

The results confirm that both global market conditions and a country's economic fundamentals play a key role in influencing the EMBIG spread of the emerging markets in the specified sample.

In line with the theoretical model, the data confirm the positive influence of government and external debt positions on spreads and the spread-reducing impact of a higher (positive) fiscal balance. It is notable that throughout the various specifications, the coefficient of external debt is roughly double that of government debt. Given that a sizeable proportion of emerging market external debt is government debt (see the pairwise correlation in Table 2 in the Appendix) this should not be overly surprising, but it does support the notion that markets are generally more concerned about government debt that is held by non-residents, as this results in both solvency and liquidity considerations. The current account balance on the other hand does not appear to be significant. Given the conflicting results (and respective arguments in support of them) in the literature, this is not particularly surprising. Furthermore, in line with expectations, exchange rate volatility and political stability are highly significant in explaining the spreads in the panel.

In addition, the results of this study confirm those of numerous similar studies, which show that global factors have an important bearing on emerging market bond spreads. The results show that a higher risk-free US interest rate tends to reduce spreads, while expectations of increasing volatility, as measured by the VIX, tend to increase spreads. These global factors remain significant throughout the various regressions. Specifications [4] and [5] in Table 3 (see Appendix) show that emerging market specific sentiment (MSCI) is a relevant predictor of sovereign spreads, but these specifications force the exclusion of the risk-free rate (US10). The risk-free rate is preferred as a variable, given its relevance in the theoretical framework.

With regard to the GFSN, the study finds a small, but statistically significant, risk-reducing correlation between the GFSN access indicator and spreads, in line with a priori expectations. When the separate elements of the GFSN are considered in Table 4 (see Appendix), the results indicate that when considered in isolation, the level of foreign exchange reserves ${ }^{17}$ has a higher risk-reducing

\footnotetext{
${ }^{17}$ No consideration is made for 'adequate levels' of reserves, instead the impact on spreads from the overall level of international reserves as a percentage of GDP is estimated.
} 
impact on spreads than GFSNacc. These results are interesting, particularly given the question proposed by Edwards (1983), who asked how the perceived probability of default would be affected if countries increased their indebtedness to finance the accumulation of international reserves. Considering the outcomes in Table 4 (see Appendix), it appears that increasing external debt to finance foreign reserve accumulation would not decrease spreads, whilst the same appears to hold for using government funds (even without a variable to account for debt servicing costs).

The results also point to a statistically significant negative correlation between access to an RFA and a country's risk spread, even though it appears smaller than the impact of foreign exchange reserves. This supports the recent increased attention RFAs have received since the GFC and lends further credence to the G20's efforts to improve communication and cooperation amongst RFAs and between RFAs and the IMF.

BSAs on the other hand appear to have no statistically significant impact on spreads. This outcome could be a result of the limited number of swap lines available to emerging markets, or the small size of such swap lines relative to the rest of the GFSN. On the other hand, it may also be an indication that swap lines are not seen as a liquidity buffer that the sovereign may use to repay foreign debt obligations. Furthermore, the People's Bank of China provides the bulk of swap lines available to emerging markets, and these are not to be used only in times of balance of payments crises, but are also often used for trade facilitation purposes.

With respect to available IMF resources, there appears to be a significant negative correlation between FCC and spreads in specification [11] in Table 4 (see Appendix). However, this result should be interpreted with caution, as available IMF resources depend on various factors including the uptake of IMF programmes and changes in available IMF funding. Both may be directly driven by financial market and global macroeconomic developments. Therefore, even as the correlation is theoretically sound, it is difficult to draw conclusions regarding causality.

The specifications which investigate the impact of IMF programmes are particularly interesting. The positive and significant coefficient for the IMF programme dummy in specification [16] in Table 5 (see Appendix) suggests that - after controlling for macroeconomic and global factors - IMF programmes in general ${ }^{18}$ appear positively correlated with risk premiums. ${ }^{19}$ At the same time, the results indicate that access to the new precautionary programmes, as measured through the FCL access dummy, as well as the volume committed under the FCL as a percentage of GDP, appears to have a statistically significant risk-reducing impact on spreads.

\footnotetext{
${ }^{18}$ Including all conventional and precautionary credit facilities.

${ }^{19}$ For robustness this specification was tested with up to 12 lags of the dummy variable, the correlation remains significant throughout.
} 
Naturally, this result could suffer from bias, considering the limited number of countries which took up the FCL and the confirmation bias related to the fact that FCLs were only offered to countries with strong fundamentals in the first place. In order to correct for potential issues of endogeneity, the panel is limited to 13 countries which are believed to have qualified for the FCL in specifications [17] and [18]. The IMF does not publicly release information regarding which countries qualified for the FCL, so the study identifies a list of countries - using a similar methodology as Maurini (2017) - which essentially identifies countries with fundamentals at least as strong as the weakest country which took up an FCL. Even though the coefficients for the FCL access dummy and the volume committed under the FCL in these specifications did decrease, the results remained significant. While it cannot be ruled out that there might be other economic or political variables at play, the results indicate that there is a negative relationship between access to an FCL and a country's risk premium.

\section{Conclusion}

The objective of this paper was to analyse whether different layers of the GFSN have an impact on emerging market bond spreads when controlling for a set of domestic and global conditions. Generally, the results underline the significant role that economic fundamentals such as economic growth and level of indebtedness play in the determination of emerging market spreads. At the same time, it becomes evident that sovereign financing costs are not only in the hands of the respective governments, but are also dependent on global economic and financial conditions. The significance and magnitude of the coefficients of external variables in all the various specifications confirms this view.

In addition, the results also provide valuable information concerning the correlation of the GFSN and a country's risk premiums. However, caution needs to be exercised when interpreting the results, given that the endogeneity problem with regard to certain GFSN variables and the risk spread cannot be completely resolved. Furthermore, the analysis did not account for RFA heterogeneity or the fact that, to date, the available observations on access to the FCL which could be considered in this study were limited.

With these caveats in mind, the results indicate that liquidity buffers provided either through self-insurance or access to an RFA tend to decrease the risk premium, with the former being more effective. The results also indicate that standard IMF programmes appear positively correlated to risk premiums. Taking into account that a country usually enters into these programmes when it is already in crisis, it is reasonable to assume that the spreads had already increased before the IMF programme was set up. However, since these upward forces on spreads should be captured by the domestic variables in the lead-up to a programme being announced, the results suggest that in the specified country 
sample, a standard IMF programme does not necessarily help to decrease risk spreads, at least in the short term. The result instead supports the existence of stigma attached to conventional IMF programmes.

In contrast to standard IMF programmes, access to the FCL, the IMF's new precautionary instrument, is negatively correlated with the risk spread of the country concerned. This finding is in line with the 'insurance' role that the precautionary instrument is intended to play. Furthermore, by limiting the sample to countries that are assumed to have been eligible for an FCL arrangement, it may be possible to conclude a causal relationship. Taking into account that there are a number of papers that could not find a significant influence of the FCL on spreads, the findings of this study may be an indication that investor perception and awareness of the FCL has changed over time. Considering that three countries have now had access to the credit line since 2009, investors might have become more familiar with the instrument. However, it remains unclear whether investors primarily value the financial resources that are committed under the FCL, or whether they take up the signal about the strong policies and fundamentals that the IMF intends to send. The fact that both the dummy variable and the volume variable are statistically significant could be an indication that both factors matter. Nonetheless, the results from this study support the findings of Essers and Ide (2019) and suggest that the perceived stigma surrounding precautionary IMF facilities - and the FCL in particular - appears unwarranted.

Turning to the policy implications of the results, it can be concluded that risk spreads appear to be mainly determined by global market conditions, and a country's economic fundamentals. A sustainable level of external debt, the buildup of a strong foreign exchange reserve buffer, as well as a stable financial and political environment are factors that lie directly in the hands of governments themselves, and which appear very effective in reducing risk spreads. At the same time, the results confirm the correlation between global conditions and risk spreads, highlighting the vulnerability of emerging markets during times of stressful external conditions, particularly as the global financial system has become more integrated over time. Besides the positive impact of accumulating foreign exchange reserves, the results also suggest that access to the GFSN through an RFA and/or FCL can be meaningful in reducing a country's perceived riskiness. Given this result, questions surrounding the provision of financial resources on a regional and global level, including access criteria, remain relevant in order to avoid unintended consequences of the GFSN.

This paper's findings cannot address the question of whether GFSN access actually reduces sovereign risk, or simply reduces the perception thereof. This issue warrants attention, as this would help prevent misalignments and mispricing of risk, which would in fact be counter-productive to the GFSN's purpose.

Nonetheless, the issues discussed here are clearly rather complex and further research on the topic is warranted, especially with regards to the characteristics 
of effective RFAs and the effectiveness of non-financial programmes, such as the newly introduced non-financing policy coordination instrument (PCI) of the IMF, and the extent to which such programmes could assist in providing positive signalling effects to market participants even without the provision of financial resources.

\section{References}

Aizenman, J., Jinjarak, Y. and Park, D. (2010). International Reserves and Swap Lines: Substitutes or Complements? NBER Working Paper, N 15804.

Bellas, D., Papaioannou, M. G. and Petrova, I. (2010). Determinants of Emerging Market Sovereign Bond Spreads: Fundamentals vs Financial Stress. IMF Working Paper, N 281.

Comelli, F. (2012). Emerging Market Sovereign Bond Spreads: Estimation and BackTesting. Emerging Markets Review, 13(4), pp. 598-625

Csonto, B. and Ivaschenko, I. (2013). Determinants of Sovereign Bond Spreads in Emerging Markets: Local Fundamentals and Global Factors vs. Ever-Changing Misalignments. IMF Working Paper, N 164.

De Grauwe, P. and Ji, Y. (2013). Self-Fulfilling Crises in the Eurozone: An Empirical Test. Journal of International Money and Finance, 34, pp. 15-36.

Denbee, E., Jung, C. and Paterno, F. (2016). Stitching Together the Global Financial Safety Net. Questioni die Economia e Finanza (Bank of Italy Occasional Paper), N 322.

Dominguez, K. M. E., Hashimoto, Y. and Ito, T. (2011). International Reserves and the Global Financial Crisis. NBER Working Paper, N 17362.

Edwards, S. (1983). LDC's Foreign Borrowing and Default Risk: An Empirical Investigation 1976-1980. NBER Working Paper Series, N 1172.

Essers, D. and Ide, S. (2019). The IMF and Precautionary Lending: An Empirical Evaluation of the Selectivity and Effectiveness of the Flexible Credit Line. Journal of International Money and Finance, 92, pp. 25-61.

European Central Bank (2016). The Layers of the Global Financial Safety Net: Taking Stock. Economic Bulletin, 5.

Fernandez-Arias, E. and Levy-Yeyati, E. (2010). Global Financial Safety Nets: Where Do We Go from Here? IDB Working Paper Series, N 231.

Giordano, L., Linciano, N. and Soccorso, P. (2012). The Determinants of Government Yield Spreads in the Euro Area. CONSOB Working Paper, N 71.

International Monetary Fund (2013). Stocktaking the Fund's Engagement with Regional Financing Arrangements. IMF Policy Paper.

International Monetary Fund (2014). Review of the Flexible Credit Line, the Precautionary and Liquidity Line, and the Rapid Financing Instrument. IMF Policy Paper.

International Monetary Fund (2015). Assessing Reserve Adequacy - Specific Proposals. IMF Policy Paper.

International Monetary Fund (2016). Adequacy of the Global Financial Safety Net. IMF Policy Paper. 
Izquierdo, A. and Talvi, E. (2009). A Stability Pact a la Maastricht for Emerging Markets. VoxEU.org, 12 December. Available at: https://voxeu.org/article/future-internationallender-last-resort-facilities [accessed on 5 May 2019].

Levy-Yeyati, E. (2008). The Cost of Reserves. Economics Letters, 100(1), pp. 39-42.

Maltritz, D. (2012). Determinants of Sovereign Yield Spreads in the Eurozone: A Bayesian Approach. Journal of International Money and Finance, 31(3), pp. 657-672.

Maurini, C. (2017). The IMF Safety Net and Emerging Markets Sovereign Spreads. Questioni di Economia e Finanza (Bank of Italy Occasional Paper), N 370.

Mc Guire, P. and Schrijvers, M. (2003). Common Factors in Emerging Market Spreads. BIS Quarterly Review, December, pp. 65-78.

Pesaran, M. H., Shin, Y. and Smith, R. P. (1999). Pooled Mean Group Estimation of Dynamic Heterogeneous Panels. Journal of the American Statistical Association, 94(446), pp. 621-634.

Scheubel, B. and Stracca, L. (2016). What do We Know about the Global Financial Safety Net? Rationale, Data and Possible Evolution. ECB Occasional Paper Series, N 177.

Volz, U. (2016). Toward the Development of a Global Financial Safety Net or a Segmentation of the Global Financial Architecture? Emerging Markets Finance and Trade, 52(10), pp. 2221-2237. 


\section{APPENDIX}

Table 1. Common sample summary statistics

\begin{tabular}{lcccc} 
Variable & Mean & Standard Deviation & Minimum & Maximum \\
\hline EMBIG & 5.51 & 0.82 & 3.59 & 8.80 \\
\hline rGDP & 3.92 & 5.83 & -33.62 & 58.99 \\
\hline CPI & 5.37 & 5.38 & -2.26 & 19.72 \\
\hline CAB & -0.22 & 5.29 & -27.13 & 152.73 \\
\hline ExD & 46.42 & 30.12 & 5.73 & 126.70 \\
\hline GvD & 37.33 & 18.07 & 4.53 & 4.74 \\
\hline Gvol & 1.87 & 1.09 & -2.67 & 4.48 \\
\hline EIP & 3.78 & 0.32 & 2.83 & 1.85 \\
\hline US10 & 1.14 & 0.38 & 0.43 & 3.95 \\
\hline VIX & 2.94 & 0.33 & 2.42 & 77.26 \\
\hline MSCI & 9.02 & 28.14 & -54.48 & 50.03 \\
\hline IntRes & 18.57 & 9.98 & 0.53 & 71.21 \\
\hline RFA & 4.47 & 10.03 & 0 & 13.20 \\
\hline BSA & 0.74 & 1.78 & 0 & 1.55 \\
\hline FCC & 1.18 & 0.21 & 0.42 & 9.20 \\
\hline FB & -1.46 & 2.65 & -8.53 & \\
\hline
\end{tabular}

Table 2. Pairwise correlation

EMBIG rGDP CPI CAB ExD GvD Gvol EIP US10 VIX MSCI IntRes RFA BSA FCC FB

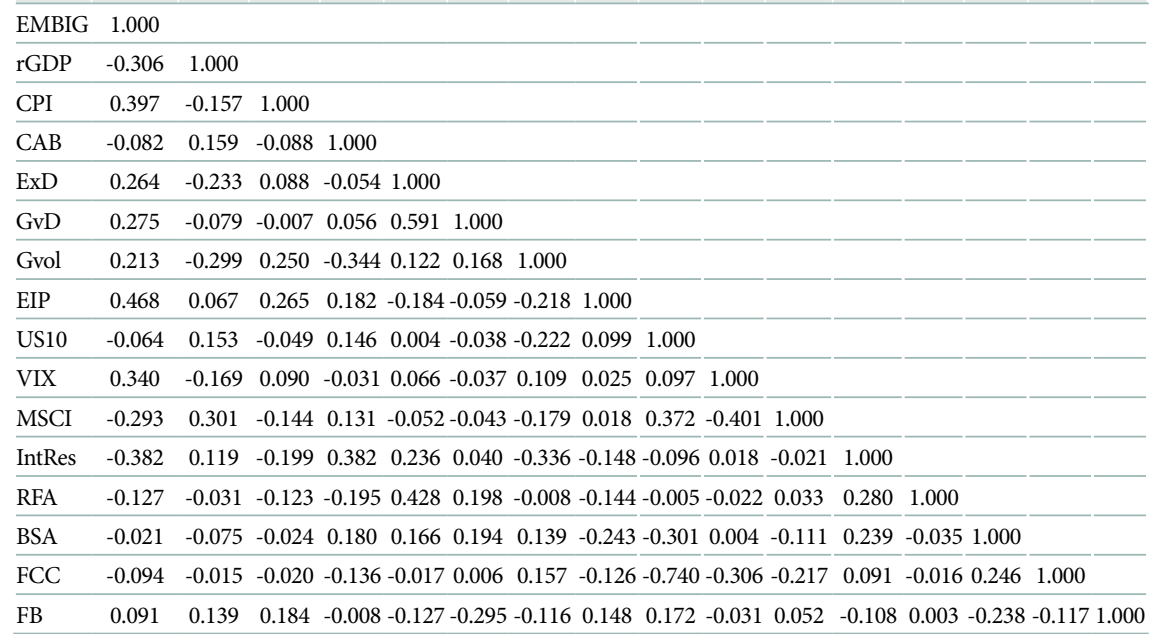


Table 3. Impact of domestic fundamentals, international factors and GFSN access on EM bond spreads

\begin{tabular}{|c|c|c|c|c|c|c|c|}
\hline & [1] & [2] & [3] & [4] & [5] & [6] & [7] \\
\hline rGDP & $\begin{array}{c}-0.01^{* * *} \\
{[0.002]}\end{array}$ & $\begin{array}{c}-0.011^{* * *} \\
{[0.002]}\end{array}$ & $\begin{array}{c}-0.01^{* * *} \\
{[0.002]}\end{array}$ & $\begin{array}{c}-0.006^{* * *} \\
{[0.002]}\end{array}$ & $\begin{array}{c}-0.008^{* * *} \\
{[0.002]}\end{array}$ & $\begin{array}{c}-0.009^{* * *} \\
{[0.002]}\end{array}$ & $\begin{array}{c}-0.009^{* * *} \\
{[0.002]}\end{array}$ \\
\hline CPI & $\begin{array}{l}-0.004^{*} \\
{[0.002]}\end{array}$ & $\begin{array}{c}0.002^{*} \\
{[0.001]}\end{array}$ & & $\begin{array}{c}-0.006^{\star \star} \\
{[0.002]}\end{array}$ & $\begin{array}{l}0.004^{* *} \\
{[0.002]}\end{array}$ & $\begin{array}{c}-0.004 \\
{[0.003]} \\
\end{array}$ & \\
\hline $\mathrm{CAB}$ & $\begin{array}{l}-0.002 \\
{[0.003]}\end{array}$ & & $\begin{array}{c}-0.001 \\
{[0.003]}\end{array}$ & $\begin{array}{c}0.001 \\
{[0.003]}\end{array}$ & $\begin{array}{c}0.004 \\
{[0.003]}\end{array}$ & $\begin{array}{c}0.001 \\
{[0.003]}\end{array}$ & $\begin{array}{c}0.001 \\
{[0.003]}\end{array}$ \\
\hline ExD & $\begin{array}{c}0.016^{\star * *} \\
{[0.001]}\end{array}$ & $\begin{array}{c}0.015^{* * *} \\
{[0.001]}\end{array}$ & $\begin{array}{c}0.016^{\star * *} \\
{[0.001]}\end{array}$ & $\begin{array}{c}0.016^{\star * *} \\
{[0.001]}\end{array}$ & $\begin{array}{c}0.015^{\star * *} \\
{[0.001]}\end{array}$ & $\begin{array}{c}0.016^{* * *} \\
{[0.001]}\end{array}$ & $\begin{array}{c}0.016^{\star * *} \\
{[0.001]}\end{array}$ \\
\hline GvD & $\begin{array}{c}0.007^{* * *} \\
{[0.002]}\end{array}$ & $\begin{array}{c}0.007^{* * *} \\
{[0.001]}\end{array}$ & $\begin{array}{c}0.007^{* * *} \\
{[0.002]}\end{array}$ & $\begin{array}{c}0.007^{* * *} \\
{[0.002]}\end{array}$ & $\begin{array}{c}0.008^{* * *} \\
{[0.001]}\end{array}$ & $\begin{array}{c}0.007^{* * *} \\
{[0.002]}\end{array}$ & $\begin{array}{c}0.007^{* * *} \\
{[0.002]}\end{array}$ \\
\hline $\mathrm{FB}$ & $\begin{array}{c}-0.011^{\star *} \\
{[0.005]}\end{array}$ & & $\begin{array}{c}-0.013^{* *} \\
{[0.005]}\end{array}$ & $\begin{array}{c}-0.017^{\star * *} \\
{[0.005]}\end{array}$ & & $\begin{array}{c}-0.01^{*} \\
{[0.005]}\end{array}$ & $\begin{array}{c}-0.011^{\star *} \\
{[0.005]}\end{array}$ \\
\hline lnGvol & $\begin{array}{c}0.061^{* * *} \\
{[0.015]}\end{array}$ & $\begin{array}{c}0.053^{* * *} \\
{[0.014]}\end{array}$ & $\begin{array}{c}0.056^{* * *} \\
{[0.015]}\end{array}$ & $\begin{array}{c}0.063^{* * *} \\
{[0.014]}\end{array}$ & $\begin{array}{c}0.059^{* * *} \\
{[0.014]}\end{array}$ & $\begin{array}{c}0.076^{* * *} \\
{[0.015]}\end{array}$ & $\begin{array}{c}0.069^{* * *} \\
{[0.015]}\end{array}$ \\
\hline $\operatorname{lnEIP}$ & $\begin{array}{c}0.936^{\star * *} \\
{[0.102]}\end{array}$ & $\begin{array}{c}0.905^{\star * *} \\
{[0.092]}\end{array}$ & $\begin{array}{c}0.914^{\star * *} \\
{[0.104]}\end{array}$ & $\begin{array}{c}0.903^{* * *} \\
{[0.1]}\end{array}$ & $\begin{array}{c}0.718^{\star * *} \\
{[0.089]}\end{array}$ & $\begin{array}{c}0.821^{\star * *} \\
{[0.103]}\end{array}$ & $\begin{array}{c}0.796^{\star * *} \\
{[0.105]}\end{array}$ \\
\hline $\operatorname{lnUS} 10$ & $\begin{array}{c}-0.133^{* * *} \\
{[0.032]}\end{array}$ & $\begin{array}{c}-0.116^{* * *} \\
{[0.031]}\end{array}$ & $\begin{array}{c}-0.135^{\star * *} \\
{[0.033]}\end{array}$ & $\begin{array}{c}-0.029 \\
{[0.035]}\end{array}$ & $\begin{array}{c}-0.055 \\
{[0.036]}\end{array}$ & $\begin{array}{c}-0.177^{\star * *} \\
{[0.036]}\end{array}$ & $\begin{array}{c}-0.173^{* * *} \\
{[0.036]}\end{array}$ \\
\hline $\operatorname{lnVIX}$ & $\begin{array}{c}0.705^{* * *} \\
{[0.032]}\end{array}$ & $\begin{array}{c}0.704^{* * *} \\
{[0.031]}\end{array}$ & $\begin{array}{c}0.701^{* * *} \\
{[0.031]}\end{array}$ & $\begin{array}{c}0.584^{* * *} \\
{[0.034]}\end{array}$ & $\begin{array}{l}0.58^{* * *} \\
{[0.033]}\end{array}$ & $\begin{array}{c}0.698^{* * *} \\
{[0.031]}\end{array}$ & $\begin{array}{c}0.696^{* * *} \\
{[0.031]}\end{array}$ \\
\hline $\operatorname{lnMSCI}$ & & & & $\begin{array}{c}-0.003^{* * *} \\
{[0.001]}\end{array}$ & $\begin{array}{c}-0.003^{* * *} \\
{[0.001]}\end{array}$ & & \\
\hline GFSNacc & & & & & $\begin{array}{c}-0.007^{\star * *} \\
{[0.002]}\end{array}$ & $\begin{array}{c}-0.007^{\star * *} \\
{[0.002]}\end{array}$ & $\begin{array}{c}-0.007^{\star * *} \\
{[0.002]}\end{array}$ \\
\hline Constant & $\begin{array}{c}-1.029^{* * *} \\
{[0.377]}\end{array}$ & $\begin{array}{c}-0.898^{* * *} \\
{[0.347]}\end{array}$ & $\begin{array}{c}-0.934^{* *} \\
{[0.386]}\end{array}$ & $\begin{array}{l}-0.643^{\star} \\
{[0.372]}\end{array}$ & $\begin{array}{c}0.257 \\
{[0.352]}\end{array}$ & $\begin{array}{c}-0.371 \\
{[0.395]}\end{array}$ & $\begin{array}{c}-0.289 \\
{[0.405]}\end{array}$ \\
\hline $\mathrm{R}^{2}$ & 0.851 & 0.841 & 0.85 & 0.856 & 0.853 & 0.849 & 0.849 \\
\hline Observations & 1131 & 1201 & 1133 & 1131 & 1162 & 1109 & 1109 \\
\hline
\end{tabular}

Note: fixed-effect regression. Robust 2-way clustered standard errors in parentheses. Dependant variable is the log of EMBIG spreads. ${ }^{* *}$ - significant at the $1 \%$ level; ${ }^{* *}$ - significant at the $5 \%$ level; ${ }^{*}$ - significant at the $10 \%$ level. 
Table 4. Impact of individual GFSN layers on EM spreads

\begin{tabular}{|c|c|c|c|c|c|c|}
\hline & {$[8]$} & [9] & [10] & [11] & [12] & [13] \\
\hline rGDP & $\begin{array}{c}-0.009^{* * *} \\
{[0.002]}\end{array}$ & $\begin{array}{c}-0.01^{\star * *} \\
{[0.002]}\end{array}$ & $\begin{array}{c}-0.01^{* * *} \\
{[0.002]}\end{array}$ & $\begin{array}{c}-0.009^{* * *} \\
{[0.002]}\end{array}$ & $\begin{array}{c}-0.009^{* * *} \\
{[0.002]}\end{array}$ & $\begin{array}{c}-0.009^{* * *} \\
{[0.002]}\end{array}$ \\
\hline CPI & $\begin{array}{c}-0.003 \\
{[0.003]}\end{array}$ & $\begin{array}{l}-0.004^{*} \\
{[0.002]}\end{array}$ & $\begin{array}{l}-0.004^{*} \\
{[0.002]}\end{array}$ & $\begin{array}{c}-0.004^{* *} \\
{[0.002]}\end{array}$ & $\begin{array}{c}-0.004 \\
{[0.003]}\end{array}$ & $\begin{array}{c}-0.004 \\
{[0.003]}\end{array}$ \\
\hline $\mathrm{CAB}$ & $\begin{array}{c}0.003 \\
{[0.003]}\end{array}$ & $\begin{array}{c}-0.002 \\
{[0.003]}\end{array}$ & $\begin{array}{c}-0.002 \\
{[0.003]}\end{array}$ & $\begin{array}{c}-0.002 \\
{[0.003]}\end{array}$ & & \\
\hline ExD & $\begin{array}{c}0.017^{\star * *} \\
{[0.001]}\end{array}$ & $\begin{array}{c}0.016^{* * *} \\
{[0.001]}\end{array}$ & $\begin{array}{c}0.016^{* * *} \\
{[0.001]}\end{array}$ & $\begin{array}{c}0.016^{* * *} \\
{[0.001]}\end{array}$ & $\begin{array}{c}0.016^{* * *} \\
{[0.001]}\end{array}$ & $\begin{array}{c}0.016^{\star * *} \\
{[0.001]}\end{array}$ \\
\hline GvD & $\begin{array}{c}0.006^{* * *} \\
{[0.002]}\end{array}$ & $\begin{array}{c}0.007^{\star * *} \\
{[0.002]}\end{array}$ & $\begin{array}{c}0.007^{\star * *} \\
{[0.002]}\end{array}$ & $\begin{array}{c}0.006^{\star * *} \\
{[0.002]}\end{array}$ & $\begin{array}{c}0.006^{* * *} \\
{[0.002]}\end{array}$ & $\begin{array}{c}0.006^{* * *} \\
{[0.002]}\end{array}$ \\
\hline $\mathrm{FB}$ & $\begin{array}{c}-0.01^{*} \\
{[0.005]}\end{array}$ & $\begin{array}{c}-0.011^{\star *} \\
{[0.005]}\end{array}$ & $\begin{array}{c}-0.011^{\star *} \\
{[0.005]}\end{array}$ & $\begin{array}{c}-0.012^{\star *} \\
{[0.005]}\end{array}$ & $\begin{array}{c}-0.01^{*} \\
{[0.005]}\end{array}$ & $\begin{array}{l}-0.01^{* *} \\
{[0.005]}\end{array}$ \\
\hline $\operatorname{lnGvol}$ & $\begin{array}{c}0.074^{* * *} \\
{[0.015]}\end{array}$ & $\begin{array}{c}0.064^{\star * *} \\
{[0.015]}\end{array}$ & $\begin{array}{c}0.059^{* * *} \\
{[0.017]}\end{array}$ & $\begin{array}{c}0.063^{\star * *} \\
{[0.015]}\end{array}$ & $\begin{array}{l}0.08^{* * *} \\
{[0.016]}\end{array}$ & $\begin{array}{c}0.083^{\star * *} \\
{[0.018]}\end{array}$ \\
\hline $\operatorname{lnEIP}$ & $\begin{array}{c}0.799^{* * *} \\
{[0.102]}\end{array}$ & $\begin{array}{c}0.955^{\star * *} \\
{[0.102]}\end{array}$ & $\begin{array}{c}0.946^{\star * *} \\
{[0.108]}\end{array}$ & $\begin{array}{c}0.896^{* * *} \\
{[0.102]}\end{array}$ & $\begin{array}{c}0.81^{* * *} \\
{[0.1]}\end{array}$ & $\begin{array}{c}0.797^{\star * *} \\
{[0.105]}\end{array}$ \\
\hline $\operatorname{lnUS10}$ & $\begin{array}{c}-0.187^{\star * *} \\
{[0.036]}\end{array}$ & $\begin{array}{c}-0.135^{\star * *} \\
{[0.032]}\end{array}$ & $\begin{array}{c}-0.129^{* * *} \\
{[0.032]}\end{array}$ & $\begin{array}{c}-0.179^{* * *} \\
{[0.04]}\end{array}$ & $\begin{array}{l}-0.23^{* * *} \\
{[0.041]}\end{array}$ & $\begin{array}{c}-0.235^{\star * *} \\
{[0.042]}\end{array}$ \\
\hline $\operatorname{lnVIX}$ & $\begin{array}{c}0.703^{* * *} \\
{[0.031]}\end{array}$ & $\begin{array}{c}0.701^{\star * \star} \\
{[0.032]}\end{array}$ & $\begin{array}{c}0.705^{\star * *} \\
{[0.032]}\end{array}$ & $\begin{array}{c}0.681^{* * *} \\
{[0.034]}\end{array}$ & $\begin{array}{c}0.667^{* * *} \\
{[0.034]}\end{array}$ & $\begin{array}{c}0.668^{* * *} \\
{[0.034]}\end{array}$ \\
\hline IntRes & $\begin{array}{c}-0.011^{\star * *} \\
{[0.002]}\end{array}$ & & & & $\begin{array}{c}-0.009^{* * *} \\
{[0.002]}\end{array}$ & $\begin{array}{c}-0.009^{\star * *} \\
{[0.003]}\end{array}$ \\
\hline RFA & & $\begin{array}{l}-0.005^{*} \\
{[0.003]}\end{array}$ & & & $\begin{array}{l}-0.005^{\star} \\
{[0.003]}\end{array}$ & $\begin{array}{l}-0.005^{*} \\
{[0.003]}\end{array}$ \\
\hline BSA & & & $\begin{array}{c}0.004 \\
{[0.008]}\end{array}$ & & & $\begin{array}{c}-0.004 \\
{[0.008]}\end{array}$ \\
\hline FCC & & & & $\begin{array}{c}-0.093^{* *} \\
{[0.042]}\end{array}$ & $\begin{array}{c}-0.103^{\star *} \\
{[0.043]}\end{array}$ & $\begin{array}{c}-0.102^{\star *} \\
{[0.042]}\end{array}$ \\
\hline Constant & $\begin{array}{c}-0.27 \\
{[0.393]}\end{array}$ & $\begin{array}{c}-1.056^{* * *} \\
{[0.375]}\end{array}$ & $\begin{array}{c}-1.067^{* * *} \\
{[0.397]}\end{array}$ & $\begin{array}{c}-1.27^{* * *} \\
{[0.399]}\end{array}$ & $\begin{array}{l}-0.738^{*} \\
{[0.398]}\end{array}$ & $\begin{array}{c}-0.677 \\
{[0.416]}\end{array}$ \\
\hline $\mathrm{R}^{2}$ & 0.848 & 0.848 & 0.847 & 0.848 & 0.846 & 0.849 \\
\hline Observations & 1119 & 1131 & 1131 & 1121 & 1128 & 1113 \\
\hline
\end{tabular}

Note: fixed-effect regression. Robust standard errors in parentheses. Dependant variable is the log of EMBIG spreads. ${ }^{* *}$ - significant at the $1 \%$ level; ${ }^{* *}$ - significant at the $5 \%$ level; ${ }^{*}$ - significant at the $10 \%$ level. 
Table 5. Impact of various measures of IMF programmes on EM spreads

\begin{tabular}{|c|c|c|c|c|c|}
\hline & [14] & [15] & [16] & [17] & [18] \\
\hline rGDP & $\begin{array}{c}-0.009^{* * *} \\
{[0.002]}\end{array}$ & $\begin{array}{c}-0.009^{* * *} \\
{[0.002]}\end{array}$ & $\begin{array}{c}-0.01^{* * *} \\
{[0.002]}\end{array}$ & $\begin{array}{c}-0.01^{* * *} \\
{[0.002]}\end{array}$ & $\begin{array}{c}-0.01^{* * *} \\
{[0.002]}\end{array}$ \\
\hline CPI & $\begin{array}{l}-0.005 \\
{[0.003]}\end{array}$ & $\begin{array}{c}-0.004 \\
{[0.003]}\end{array}$ & $\begin{array}{c}-0.003 \\
{[0.003]}\end{array}$ & $\begin{array}{c}0.034^{* * *} \\
{[0.005]}\end{array}$ & $\begin{array}{c}0.036^{* * *} \\
{[0.005]}\end{array}$ \\
\hline $\mathrm{CAB}$ & $\begin{array}{c}0.001 \\
{[0.003]}\end{array}$ & $\begin{array}{c}0.001 \\
{[0.003]}\end{array}$ & $\begin{array}{c}0.001 \\
{[0.003]}\end{array}$ & $\begin{array}{l}0.007^{* *} \\
{[0.003]}\end{array}$ & $\begin{array}{c}0.006^{*} \\
{[0.003]}\end{array}$ \\
\hline ExD & $\begin{array}{c}0.016^{* * *} \\
{[0.001]}\end{array}$ & $\begin{array}{c}0.016^{* * *} \\
{[0.001]}\end{array}$ & $\begin{array}{c}0.015^{* * *} \\
{[0.001]}\end{array}$ & $\begin{array}{c}0.018^{* * *} \\
{[0.001]}\end{array}$ & $\begin{array}{c}0.018^{* * *} \\
{[0.001]}\end{array}$ \\
\hline GvD & $\begin{array}{c}0.008^{* * *} \\
{[0.002]}\end{array}$ & $\begin{array}{c}0.007^{* * *} \\
{[0.002]}\end{array}$ & $\begin{array}{c}0.006^{* * *} \\
{[0.002]}\end{array}$ & $\begin{array}{l}0.01^{* * *} \\
{[0.002]}\end{array}$ & $\begin{array}{l}0.01^{* * *} \\
{[0.002]}\end{array}$ \\
\hline FB & $\begin{array}{l}-0.009^{*} \\
{[0.005]}\end{array}$ & $\begin{array}{l}-0.01^{* *} \\
{[0.005]}\end{array}$ & $\begin{array}{c}-0.011^{* *} \\
{[0.005]}\end{array}$ & $\begin{array}{c}-0.013^{* *} \\
{[0.005]}\end{array}$ & $\begin{array}{c}-0.015^{* * *} \\
{[0.006]}\end{array}$ \\
\hline $\operatorname{lnGvol}$ & $\begin{array}{c}0.073^{* * *} \\
{[0.016]}\end{array}$ & $\begin{array}{c}0.075^{* * *} \\
{[0.016]}\end{array}$ & $\begin{array}{c}0.075^{\star * *} \\
{[0.015]}\end{array}$ & $\begin{array}{c}0.078^{* * *} \\
{[0.015]}\end{array}$ & $\begin{array}{l}0.08^{* * *} \\
{[0.015]}\end{array}$ \\
\hline $\operatorname{lnEIP}$ & $\begin{array}{c}0.753^{* * *} \\
{[0.104]}\end{array}$ & $\begin{array}{c}0.799^{* * *} \\
{[0.103]}\end{array}$ & $\begin{array}{c}0.803^{* * *} \\
{[0.101]}\end{array}$ & $\begin{array}{c}0.818^{* * *} \\
{[0.109]}\end{array}$ & $\begin{array}{c}0.848^{* * *} \\
{[0.108]}\end{array}$ \\
\hline $\ln U S 10$ & $\begin{array}{c}-0.213^{* * *} \\
{[0.036]}\end{array}$ & $\begin{array}{c}-0.187^{\star * *} \\
{[0.036]}\end{array}$ & $\begin{array}{c}-0.182^{\star * *} \\
{[0.036]}\end{array}$ & $\begin{array}{c}-0.17^{\star * *} \\
{[0.04]}\end{array}$ & $\begin{array}{c}-0.14^{* * *} \\
{[0.04]}\end{array}$ \\
\hline $\operatorname{lnVIX}$ & $\begin{array}{c}0.702^{* * *} \\
{[0.031]}\end{array}$ & $\begin{array}{c}0.698^{* * *} \\
{[0.031]}\end{array}$ & $\begin{array}{c}0.692^{\star * *} \\
{[0.031]}\end{array}$ & $\begin{array}{c}0.671^{* * *} \\
{[0.032]}\end{array}$ & $\begin{array}{c}0.666^{* * *} \\
{[0.032]}\end{array}$ \\
\hline GFSNacc & $\begin{array}{c}-0.007^{* * *} \\
{[0.002]}\end{array}$ & $\begin{array}{c}-0.007^{* * *} \\
{[0.002]}\end{array}$ & $\begin{array}{c}-0.007^{* * *} \\
{[0.002]}\end{array}$ & $\begin{array}{c}-0.007^{* * *} \\
{[0.002]}\end{array}$ & $\begin{array}{c}-0.007^{* * *} \\
{[0.002]}\end{array}$ \\
\hline FCLdum & $\begin{array}{l}-0.23^{* * *} \\
{[0.046]}\end{array}$ & & & $\begin{array}{c}-0.176^{* * *} \\
{[0.042]}\end{array}$ & \\
\hline FCL & & $\begin{array}{c}-0.021^{\star *} \\
{[0.009]}\end{array}$ & & & $\begin{array}{l}-0.016^{*} \\
{[0.009]}\end{array}$ \\
\hline IMFprog & & & $\begin{array}{c}0.087^{* * *} \\
{[0.032]}\end{array}$ & & \\
\hline constant & $\begin{array}{c}-0.091 \\
{[0.398]}\end{array}$ & $\begin{array}{c}-0.291 \\
{[0.394]}\end{array}$ & $\begin{array}{c}-0.253 \\
{[0.392]}\end{array}$ & $\begin{array}{l}-0.713^{*} \\
{[0.406]}\end{array}$ & $\begin{array}{c}-0.838^{\star *} \\
{[0.403]}\end{array}$ \\
\hline $\mathrm{R}^{2}$ & 0.851 & 0.849 & 0.849 & 0.817 & 0.814 \\
\hline Observations & 1109 & 1109 & 1109 & 778 & 778 \\
\hline Countries & 21 & 21 & 21 & 13 & 13 \\
\hline
\end{tabular}

Note: fixed-effect regression. Robust standard errors in parentheses. Dependant variable is the log of EMBIG spreads. $^{* *}$ - significant at the $1 \%$ level; ${ }^{* *}$ - significant at the $5 \%$ level; ${ }^{*}$ - significant at the $10 \%$ level. 